\title{
Ekspresi mRNA LMP2A Epstein-Barr Virus dari Biopsi Jaringan dalam Blok Parafin Berpotensi sebagai Biomarka dalam Diagnosis Karsinoma Nasofaring
}

\author{
Roni Afriansya ${ }^{1}$, Hendro Pramono ${ }^{1}$, Hidayat Sulistyo ${ }^{2}$, Daniel Joko Wahyono ${ }^{1}$ \\ ${ }^{1}$ Fakultas Biologi Universitas Jenderal Soedirman, Purwokerto \\ Fakultas Kedokteran, Universitas Jenderal Soedirman, Purwokerto \\ Email: roniafriansya@gmail.com \\ Korespondensi : daniel.joko@unsoed.ac.id
}

\begin{abstract}
Nasopharyngeal carcinoma (NPC) is an epithelial tumor located in the nasopharynx and is a multifactorial genetic disease. The main cause of NPC is the infection of Epstein-Barr virus (EBV). The existence of EBV in NPC patients can be identified by the discovery of EBV DNA in tissue biopsy. EBV genome and the expression of part of the product of the latent gene of this virus isconsistently detected in almost eachcancer cell of NPC, one of which is a Latent Membrant Protein (LMP)gene. The activities of EBV mRNA better reflect a real pathogeneneityof NPC compared to the serological diagnosis and measurement of EBV DNAin blood circulation. The study was conducted in the laboratory of genetics and molecular Biology Faculty of Unsoed Purwokerto. Analysis of mRNA expression LMP2A EBV was performed using one step RT-PCR technique and RT-PCR product (amplicon cDNA) was visualized in $1 \%$ agarose gel electrophoresis. The mRNA LMP2A EBV can be expressedeither form samples with lowRNA concentration or samples with high mRNA concentration. However,the positivity of mRNA LMP2A EBV expression was moderate positivity (27.3\%). In conclusion, the mRNA expression of EBV LMP2A from NPC tumor biopsy tissue samples preserved in paraffin blocks was a moderate positivity, so tha mRNA expression of LMP2A EBV has a potentially be used as biomarker of NPC diagnosis.
\end{abstract}

Key words: Nasopharyngeal carcinoma, Virus Epstein-Barr, Latent Membrant Protein 2A.

\begin{abstract}
Abstrak
Karsinoma nasofaring (KNF) merupakan tumor epitel yang terletak di nasofaring dan merupakan penyakit genetik multifaktor yang endemik. Penyebab utama KNF adalah infeksi oleh Virus Epstein-Barr (EBV). Keberadaan EBV pada penderita KNF dapat diketahui dengan ditemukannya DNA EBV dalam spesimen biopsi jaringan penderita KNF. Genom EBV dan ekspresi sebagian dari produk gen laten virus secara konsisten terdeteksi hampir di setiap sel dalam kanker ini, salah satunya adalah gen Latent Membrant Protein (LMP). Aktivitas mRNA EBV lebih mencerminkan patogenesis KNF yang sesungguhnya dari pada diagnosis serologi dan pengukuran DNA EBV di sirkulasi. Penelitian dilakukan di Laboratorium PA RSUD Margono Seokarjo, Purwokerto/Lab PA Fakultas Kedokteran dan laboratorium genetika/molekuler Universitas Jenderal Soedirman Purwokerto. Analisis Ekspresi mRNA LMP2A EBV dengan teknik one step RT-PCR dan amplikon CDNA divisualisasi dengan elektroforesis gel agarosa $1 \%$. Hasil penelitian ini menunjukkan positivitas ekspresi mRNA LMP2A EBV dari biopsi jaringan KNF dalam blok paraffin adalah sedang (27,3\%). Kesimpulan, ekspresi mRNA LMP2A EBV dari biopsi jaringan tumor KNF dalam blok paraffin dengan metode one step RT-PCR dengan positivitas sedang (27,3\%), sehingga berpotensi sebagai biomarka dalam diagnosis KNF
\end{abstract}

Kata kunci: Karsinoma nasofaring, Virus Epstein-Barr, Latent Membrant Protein 2A.

\section{Pendahuluan}

KNF mempunyai sifat berbeda dibandingkan dengan keganasan pada kepala leher yang lain, karena sifatnya yang sangat invasif dan sangat mudah bermetastasis (Liu et al., 2003; Jiang et al., 2004; Ma et al., 2007; Tang et al., 2008). Salah satu penyebab KNF adalah infeksi oleh Epstein-Barr Virus (EBV) (Gu et al., 2012; Shen et al., 2015). EBV adalah herpesvirus limfotropik yang dapat menginfeksi dan bereplikasi dalam sel epitel dan limfosit B. Infeksi EBV pada sel B dan tumor KNF ditandai dengan terekspresinya gen fase laten dan gen fase litik EBV (Steven et al., 2006). Gen fase laten yaitu EBNA1, EBNA2,
EBNA3, LMP1, LMP2, EBER dan gen fase litik yaitu BRLF1, BZLF1, BALF1, BCLF1.

Kanker KNF secara konsisten mengekspresikan sebagian dari produk gen laten EBV, salah satunya adalah gen Latent Membrane Protein (LMP) (Raab-Traub and Flynn., 1986; Pittaluga et al., 1992). Ekspresi gen LMP yang terdiri dari LMP-1 dan -2 adalah onkogen EBV yang ekpresinya lebih tinggi pada pasien usia muda (<30 tahun) dan mengindikasikan replikasi virus yang tinggi dalam sel. Ekspresi gen LMP ini juga berkaitan dengan progresifitas lokal dari KNF (Adham et al., 2012). Gen LMP2A memainkan peran penting dalam menjaga kondisi infeksi laten EBV pada sel B dan berpartisipasi dalam induksi 
transformasi sel epitel tumor KNF (Dawson et al., 2012). Nakaya et al., (2013) melaporkan bahwa gen LMP2A memiliki fungsi onkogen, yaitu mampu melakukan transformasi sel normal menjadi sel tumor pada KNF, melalui peningkatan ekskresi side population (SP) yang tergantung pada aktivasi Stat3, MEK/ERK, jalur PI3K dan peningkatan ekspresi HMGA2. Oleh karena itu, analisis ekspresi gen laten LMP2A dapat digunakan untuk melihat patogenesi dan menegakkan diagnosis KNF guna meningkatkan efisiensi dalam penanganan KNF.

Pengukuran aktivitas mRNA EBV di lokasi tumor primer secara langsung pada daerah nasofaring perlu dilakukan, karena aktivitas mRNA EBV lebih mencerminkan patogenesis KNF yang sesungguhnya dari pada diagnosis serologi dan pengukuran DNA EBV di sirkulasi. Pada saat ini, analisis ekspresi mRNA EBV menggunakan teknik Reverse TranscriptasePolymerase Chain Reaction (RTPCR), karena teknik ini lebih sensitif dan efisien untuk mendeteksi mRNA dibandingkan teknik terdahulu yaitu Northern Blot. Teknik RT-PCR mampu mendeteksi mRNA yang mengalami proses pembuangan intron (spliced mRNA) dalam jumlah kecil dan memerlukan jumlah sampel klinis lebih sedikit. Tujuan penelitian ini untuk mengetahuiapakah metode Reverse Transcriptase Polymerase Chain Reaction (RTPCR) dapat mendeteksi ekspresi mRNA LMP2A EBV pada penderita KNF dan melihat positivitas ekspresi mRNA LMP2A EBV pada penderita KNF.

\section{Materi dan Metode}

Objek penelitian ini adalah biopsi jaringan tumor penderita KNF dengan diagnosis pasti dari hasil pemeriksaan Patologi Anatomi di RSUD Prof. dr. Margono Soekarjo, Purwokerto. Penelitian dilakukan selama 6 bulan dari bulan Maret 2016 sampai dengan bulan Agustus 2016 di Poli Patologi Anatomi - RSUD Prof.Dr. Margono Soekarjo Purwokerto, Lab. PA Fakultas Kedokteran dan Laboratorium Genetika/Molekuler Fakultas Biologi Univeritas Jenderal Soedirman Purwokerto.

\section{Isolasi RNA}

Sampel biopsi jaringan KNF dari Laboratorium Patologi Anatomi Poli THT RSUD Prof. dr. Margono Soekarjo kemudian di potong 8-10 slise, kemudian dimasukkan ke tube untuk proses isolasi RNA. Isolasi RNA dilakukan menggunakan kit FFPE PureLink RNA Isolation Kit - Invitrogen.

\section{Analisis ekspresi mRNA LMP2A EBV}

Analisis dilakukan dengan teknik one stepRTPCR dan menggunakan kit (SuperScript ${ }^{\mathrm{TM}}$ III One-Step RT-PCR System with Platinum ${ }^{\mathrm{TM}}$ Taq DNA Polymerase - Invitrogen).Desain primer dilakukan dengan software Primer3 dari the
GenBank Sequence Database-NCBI (accession number NC_007605.1; GenelD: 17494231). Dengan primer forward 5'CTTCTGGCTCTTCTGGGAAC-3' dan primer reverse

5 TCTGCCCGCTTCTTCGTATA-3'. Campuran PCR (PCRmix) dibuat dalam PCR tube $0,2 \mathrm{ml}$ dengan volume akhir $15 \mu \mathrm{L}$ yang bebas nuclease dan dikerjakan di dalam es dengan komposisi 7,5 um (2x Reaction Mix (a buffer containing $0.4 \mathrm{mM}$ of each dNTP, 3.2 mMMgSO4), $1 \mu \mathrm{m}$ (template RNA), $1 \mu \mathrm{m}$ (Primer forward dan primer reverse), $2 \mu \mathrm{m}$ (SuperScrift ${ }^{\mathrm{TM}}$ III RT/Platinum ${ }^{\mathrm{TM}}$ Taq Mix) $^{2}, 2,5$ $\mu \mathrm{m}$ ddH2o (Autoclaved distilled water). Campuran PCRmix dimasukkan dalam mesin PCR (Peqlab, Primus standard 25 well). Tahap amplifikasi dilakukan pada mesin PCR sebanyak 35 siklus dengan kondisi PCR siklus pertama $C D N A$ synthesis dan pre-denaturation dengan kondisi PCR $45^{\circ} \mathrm{C}$ selama 30 menit dan $94^{\circ} \mathrm{C}$ selama 2 menit. Tahap denaturasi suhu $94^{\circ} \mathrm{C}$ selama 15 detik, annealing $63,4^{\circ} \mathrm{C}$ selama 30 detik, extention suhu $68^{\circ} \mathrm{C}$ selama 1 menit dan final extention $68^{\circ} \mathrm{C}$ selama 5 menit.

\section{Hasil dan Pembahasan}

Penelitian ekspresi LMP2A EBV pada penderita KNF menggunakan 22 sampel yang diambil di Laboratorium Patologi Anatomi RSUD Dr. Margono Soekardjo Purwokerto. Karakteristik umur sampel penelitian berdasarkan usia dapat dilihat pada tabel 1.

Tabel 1. Distribusi sampel berdasarkan usia

\begin{tabular}{ccc}
\hline Usia & $\begin{array}{c}\text { Jumlah } \\
(\mathbf{n})\end{array}$ & $\begin{array}{c}\text { Persentase } \\
(\%)\end{array}$ \\
\hline $0-10$ tahun & 0 & 0 \\
$11-20$ tahun & 0 & 0 \\
$21-30$ tahun & 2 & 9,1 \\
$31-40$ tahun & 4 & 18,2 \\
$41-50$ tahun & 6 & 27,3 \\
$51-60$ tahun & 7 & 31,8 \\
$>60$ tahun & 3 & 13,6 \\
Total & 22 & 100 \\
\hline
\end{tabular}

Pada tabel 1 dapat dilihat distribusi sampel penderita KNF tertinggi yaitu pada rentang usia 51-60 tahun yaitu 7 pasien $(31,8 \%)$, dan terbanyak kedua yaitu rentang usia 41-50 tahun yaitu 6 pasien $(27,3 \%)$. Mayoritas penderita KNF pada usia lebih dari 40 tahun, karena pada usia tersebut diperkirakan sudah terjadi akumulasi paparan faktor lingkungan berupa bahan-bahan karsinogen yang sudah melebihi batas ambang terjadinya tumorigenesis. Hasil penelitian ini juga sesuai dengan hasil penelitian Adham et al, (2012) yang memperoleh data distribusi KNF di Rumah sakit Cipto Mangunkusomo yaitu rentang usia 41-50 sebanyak 32,4\%, usia 31-40 sebanyak $23,4 \%$, dan usia $51-60$ sebanyak $16,4 \%$. 
Infeksi KNF ini juga dipengaruhi oleh jenis kelamin.Beberapa penelitian terdahulu menunjukkan bahwa penderita KNF bersifat dominan pada jenis kelamin laki-laki. Pada penelitian ini, proporsi jeniskelamin penderita KNF yang diperoleh adalah pada laki-laki sebanyak $63,6 \%$ dan penderita perempuan sebanyak $36,4 \%$ atau dengan berbandingan 1,8:1. Perbandingan proporsi infeksi antara laki-laki dan perempuan dapat di lihat pada gambar 1 . Hasil penelitian ini sesuai dengan penelitian terdahulu yang menunjukkan bahwa kejadian infeksi KNF lebih banyak pada laki-laki dibanding perempuan, dengan rasio 2-3:1 (Mutiarangura et al., 1997).

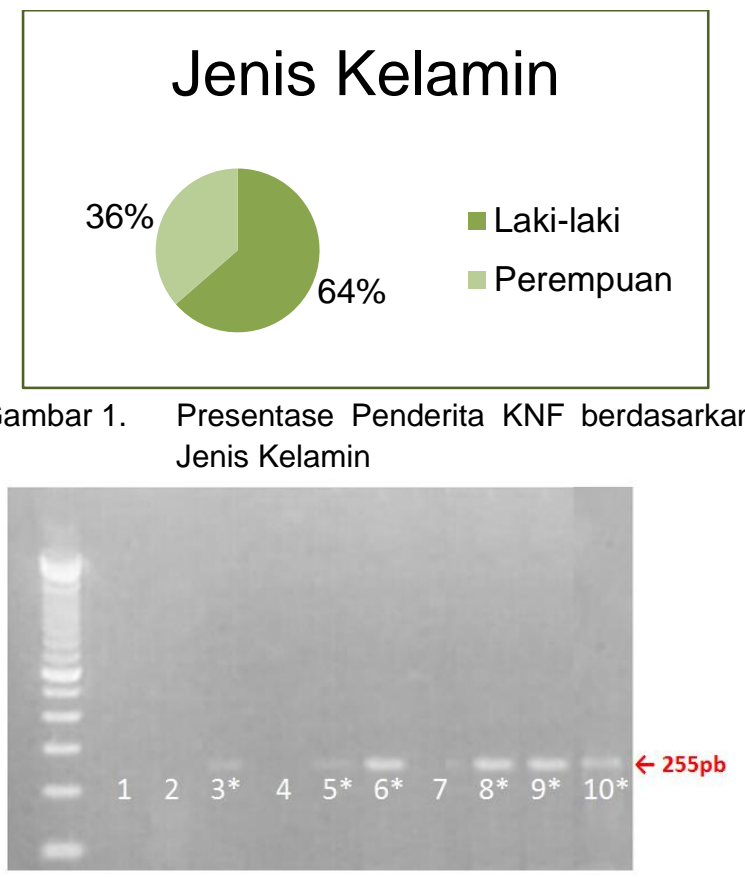

Gambar 2. Hasil visualisasi Ekspresi mRNA LMP2A EBV dengan teknik RT-PCR pada sampel biopsi jaringan KNF dalam blok paraffin (M = Marker DNA 100 pb; 1 sampai 10= urutan sumuran; * = Sampel positif ekspresi mRNA LMP2A dengan nomor sampel 3(2487), 5(2465), 6(2558), 8(840), 9(713), 10(2822); * $\neq$ sampel negatifekspresi mRNA LMP2A1(2142), 2(2721), 4(3738) dan 7(4010).

Hasil analisis ekspresi mRNA LMP2A EBV dengan menggunakan teknik one step RT-PCR tertera pada Gambar 2. Pada Gambar 2 dapat dilihat bahwa mRNA LMP2A EBV dapat terekspresi pada sampel nomo nomor 3(2487), 5(2465), 6(2558), 8(840), 9(713), 10(2822) dan negatif nomor 1(2142), 2(2721), 4(3738) dan 7(4010). Hasil positif ekspresi mRNA LMP2A EBV menunjukkan ketebalan pita yang tidak sama terutama disebabkan oleh kadar ekspresi mRNA LMP2A EBV pada konsentrasi template RNA yang sama pada tiap masing-masing sampel. Hasil negatif ekspresi mRNA LMP2A EBV terutama disebabkan oleh tidak terekspresinya mRNA LMP2A EBV. Namun, beberapa faktor yang memungkinkan tidak terkespresi mRNA LMP2A EBV yaitu tidak terjadi proses sintesis cDNA (suhu terlalu tinggi), kontaminasi Rnase, dan RNA yang telah rusak atau terdegradasi.

Hasil penelitian ini menunjukkan positivitas ekspresi mRNA LMP2A EBV sebesar 27,3\% (6 dari total 22 sampel) termasuk positivitas sedang (moderate positivity) berkisar 10-50 \% (Middeldorp et al, 2003). Hasil penelitian ini berbeda dengan penelitian terdahulu pada kasus KNF menggunakan metode RT-PCR yang menunjukkan positivitas ekspresi mRNA LMP2A EBV pada biopsi jaringan tumor KNF segar (fresh biopsy) lebih dari 98 \% (Brooks et al., 1992; Busson et al, 1992). Rendahnya hasil positivitas ekspresi mRNA LMP2A EBV dalam penelitian ini diperkirakan disebabkan oleh sampel yang digunakan berasal dari biopsi jaringan tumor dalam blok paraffin yang sudah terkontaminasi dengan formalin (formaldehid). Formalin adalah fiksatif tradisional yang telah digunakan selama beberapa dekade untuk mengawetkan jaringan di patologi (Chu et al., 2002). Fiksasi formalin yang bukan buffer formalin $10 \%$ dalam teknik patologi anatomi dapat menyebabkan asam nukleat terfragmentasi, sehingga kualitas RNA yang diperoleh sangat rendah (Lahr et al., 2002). RNA yang berasal dari spesimen tersebut secara signifikan mengalami degradasi, karena formalin menyebabkan cross-link antara asam nukleat dan protein. Penyimpanan sel atau jaringan dalam periode waktu yang panjang sebelum dilakukannya isolasi RNA juga meningkatkan degradasi RNA, karena sifat dari molekul ini yang sangat labil (Catts et al., 2005). Berdasarkan hasil penelitian Jarzab et al, (2008) yang menyatakan bahwa hasil isolasi RNA dari sampel blok paraffin menunjukkan kualitas RNA yang diperoleh sangat buruk yang disebabkan oleh degradasi RNA yang tinggi. Oleh karena itu, dapat diduga bahwa kualitas RNA yang rendah pada sampel penelitian ini telah menjadi penyebab tidak terekspresinya mRNA LMP2A pada beberapa sampel penelitian yang digunakan, meskipun secara kuantitas konsentrasi RNA hasil isolasi cukup tinggi.

\section{Simpulan}

Ekspresi mRNA LMP2A EBV dari biopsi jaringan tumor KNF dalam blok paraffin dengan metode one step RT-PCR dengan positivitas sedang $(27,3 \%)$, sehingga berpotensi sebagai biomarka dalam diagnosis KNF.

\section{Ucapan Terima Kasih}

Ucapan terima kasih disampaikan kepada Direktorat Penelitian \& Pengadian Masyarakat Kemenristekdikti atas pendanaan penelitian ini melalui Hibah Penelitian Fundamental Tahun 2015-2016 dan LPPM Unsoed sebagai pengelola pendaanan penelitian ini.. 


\section{Daftar Referensi}

Adham, M., Kurniawan, A.N., Muhtadi, A.I., Roezin, A., Hermani, B., Gondhowiardjo, S., Tan, I.B., Middeldorp, J.M. 2012. Nasopharyngeal Carcinoma in Indonesia: Epidemiology, Incidence, Signs, and Symptoms at Presentation. Chinese Journal Cancer 31(4): 185-196.

Brooks, L., Yao, Q.Y., Rickinson, A.B., and Young, L.S. 1992. Epstein-Barr Virus Latent Gene Transcription in Nasopharyngeal Carcinoma Cells: Coexpression of EBNA1, LMP1, and LMP2 Transcripts. Journal of virology 66(5): 2689-2697.

Busson, P., McCoy, R., Sadler, R., Gilligan, K., Tursz, T., Raab-Traub, N. 1992. Consistent Transcription of the Epstein-Barr Virus LMP2 Gene in Nasopharyngeal Carcinoma. Journal of virology 66(5): 3257-3262.

Catts, V. S., Catts, S. V., Fernandez, H. R., Taylor, J. M., Coulson, E. J., and LutzeMann, L. H. 2005. A Microarray Study of Post-mortem mRNA Degradation in Mouse Brain Tissue.Molecular brain research 138(2): 164-177.

Chu, W.S., Furusato, B., Wong, K., Sesterhenn, I.A., Mostofi, F.K., Wei, M.Q., Zhu, Z., Abbondanzo, S.L., Liang, Q. 2005. Ultrasound-accelerated Formalin Fixation of Tissue Improves Morphology, Antigen and mRNA Preservation. Modern pathology 18(6): 850-863.

Dawson, C.W., Port, R.J., Young, L.S. 2012. The Role of The EBV-encoded Latent Membrane Proteins LMP1 and LMP2 in The Pathogenesis of Nasopharyngeal Carcinoma (NPC).Seminar in Cancer Biology 22(2): 144153.

Fles, R., M.A.Wildemen., Beni S., Sofia, M.H., I. Bing, T. 2010. Knowledge of General Practitioners About Nasopharyngeal Cancer at The Puskesmas in Yogyakarta, Indonesia. BioMed Central Medical Education 10(81): 16.

Gu, A.D., Zeng, M.S., Qian, C.N. 2012. The Criteria to Confirm the Role of Epstein-Barr Virus in Nasopharyngeal Carcinoma Initiation.International Journal of Molecular Sciences 13(10): 13737-13747.

Jarzab, M., Rozanowski, P., Kowalska, M., Zebracka, J., Rudnicka, L., Stobiecka E., Jarzab,B., Stachura, J. Pawlega, J. 2008.Optimization of the Method of RNA Isolation from Paraffin Blocks to Assess
Gene Expression in Breast Cancer.Polish Journal of Pathology 59(2): 85-91.

Jian, G.T., Xuan, I., Ping, C. 2004. Expression of Matrix Metallo-proteinase-9 in Nasopharyngeal Carcinoma and Associated with Epstein Barr Virus Infection. Journal of Zheijiang University Sciences 5(10): 13041412.

Lahr, G., Starzinski-Powitz, A. and Mayer, A. 2002. Analysis of Specific Gene Expression. In: Conn PM (Ed). Methods in Enzymology 356: 271-281. Academic Press, San Diego, USA.

Liu, M.T., Hsieh, C.Y., Chang, T.H., Lin, J.P., Huang, C.C., Wang, A.J. 2003. Prognostic Factors Affecting the Outcome of Nasopharyngeal Carcinoma. Japanese Journal of Clinical Oncology 2(10): 501-508.

Lu, J., Cooper, J.S., M. Lee Anne W.M. 2010. The Epidemiology of Nasopharyngeal Carcinoma. In: Nasopharyngeal Cancer. Berlin: Springer 1-9.

Nakaya, T., Kikuchi, Y., Kunita, A., Ishikawa, S., Matsusaka, K., Hino, R., Aburatani, H., Fukayama, M. 2013. Enrichment of Stem-like Cell Population Comprises Transformation Ability of Epstein-Barr Virus Latent Membrane Protein 2A for Non-transformed Cells. Virus Research 174(1-2): 108-115.

Ma, J., Liu, L., Tang, L., Zong, J., Lin, A., Lu, T., Cui, N., Cui, C., Li, L. 2007. Retropharyngeal Lymphnode Metastasis in Nasopharyngeal Carcinoma: Prognostic Value and Staging Categories. Clinical Cancer Research 13(5): 1445-1452.

Middeldorp, J.M., Brink, A.A.T.P., van den Brule, A.J.C., Meijer, C.J.L.M. Pathogenic roles for Epstein-Barr virus (EBV) gene products in EBV-associated proliferative disorders. Crit Rev Oncol Hematol 2003; 45 : 1-36.

Munir, D.,Lutan, R., Hasibuan, M., Henny, F. 2007.Ekspresi Protein p53 Mutan pada Karsinoma Nasofaring.Majalah Kedokteran Nusantara 40(3): 167-172.

Mutiarangura A, Tanuyuttwongesse C, Porthanakasem W, Kerkhanjanarong V, Sriuranphong V. 1997. Genomic Alterations in Nasopharyngeal Carcinoma; Loss of Heterozygosity an Epstein-Barr Virus Infection. Journal Cancer 76: 770-776.

Pittaluga, S., Loke, S.L., So, K.C., Cheung, K.N., $\mathrm{Ma}, \mathrm{L} .1992$. Clonal Epstein-Barr Virus in Lymphoepithelioma-like Carcinoma of the Stomach: Demonstration of Viral Genome by 
in Situ Hybridization and Southern Blot Analysis. Modern Pathology 5(6): 661-664.

Raab-Traub N., and Flynn K., 1986. The Structure of The Termini of The Epstein-Barr Virus as a Marker of Clonal Cellular Proliferation.Cell 47(6): 883-889.

Shen, Y., Zhang, S., Sun, R., Wu, T., Qian, J. 2015. Understanding the Interplay Between Host Immunity and Epstein-Barr Virus in NPC Patients. Emerging Microbes Infections 4(20): 1-9.

Stevens, S. J., Verkuijlen, S. A., Hariwiyanto, B., Harijadi., Paramita, D.K., Fachiroh, J., Adham, M., Tan, I.B., Haryana, S.M., Middeldorp, J.M. 2006. Noninvasive Diagnosis of Nasopharyngeal Carcinoma: Nasopharyngeal Brushings Reveal High Epstein Barr Virus DNA Load and
Carcinoma- specific Viral BARF1 mRNA. International journal of cancer 119(3): 608614.

Tang, L., Li, L., Mao, Y., Liu, L., Liang, S., Chen, Y., Sun, Y., Liao, X., Tian, L., Lin, A., Liu, M., $\mathrm{Ma}$, J. 2008. Retropharyngeal Lymphnode Metastasis in Nasopharyngeal Carcinoma Detected by Magnetic Resonance Imaging: Prognostic Value and Staging Categories. Cancer 113(2): 347-354.

Wildeman, M.A., Renske, F., Marlinda, A., Ika, D.M., Ilse, L., Mara, S., Andrew, D.V., Faiziah, F., Zanil, M., Armiyanto., Middledorp, J.M., Geertin, G., Ronny, S., Tan, I.B. 2012. Short-term Effect of Different Teaching Methods on Nasopharyngeal Carcinoma for General Practicioners in Jakarta, Indonesia. PLOS ONE 7(3). 